\title{
Relationship Between Service Quality and Customer Satisfaction in Outdoor Services Activities: A Case Study of Rentas Adventure Group
}

Muhammad Wafi A. Rahman, Nur Dalilah Dahlan, Nurul Hasanah Abdul Razak, Rozita Abdul Latif, Siti Aida Lamat

To Link this Article: http://dx.doi.org/10.6007/IJARBSS/v11-i11/11301

DOI:10.6007/IJARBSS/v11-i11/11301

Received: 05 September 2021, Revised: 07 October 2021, Accepted: 24 October 2021

Published Online: 19 November 2021

In-Text Citation: (Rahman et al., 2021)

To Cite this Article: Rahman, M. W. A., Dahlan, N. D., Razak, N. H. A., Latif, R. A., \& Lamat, S. A. (2021). Relationship Between Service Quality and Customer Satisfaction in Outdoor Services Activities: A Case Study of Rentas Adventure Group. International Journal of Academic Research in Business and Social Sciences, 11(11), $1172-1179$.

\section{Copyright: @ 2021 The Author(s)}

Published by Human Resource Management Academic Research Society (www.hrmars.com)

This article is published under the Creative Commons Attribution (CC BY 4.0) license. Anyone may reproduce, distribute, translate and create derivative works of this article (for both commercial and non-commercial purposes), subject to full attribution to the original publication and authors. The full terms of this license may be seen at: http://creativecommons.org/licences/by/4.0/legalcode

Vol. 11, No. 11, 2021, Pg. $1172-1179$

Full Terms \& Conditions of access and use can be found at http://hrmars.com/index.php/pages/detail/publication-ethics 


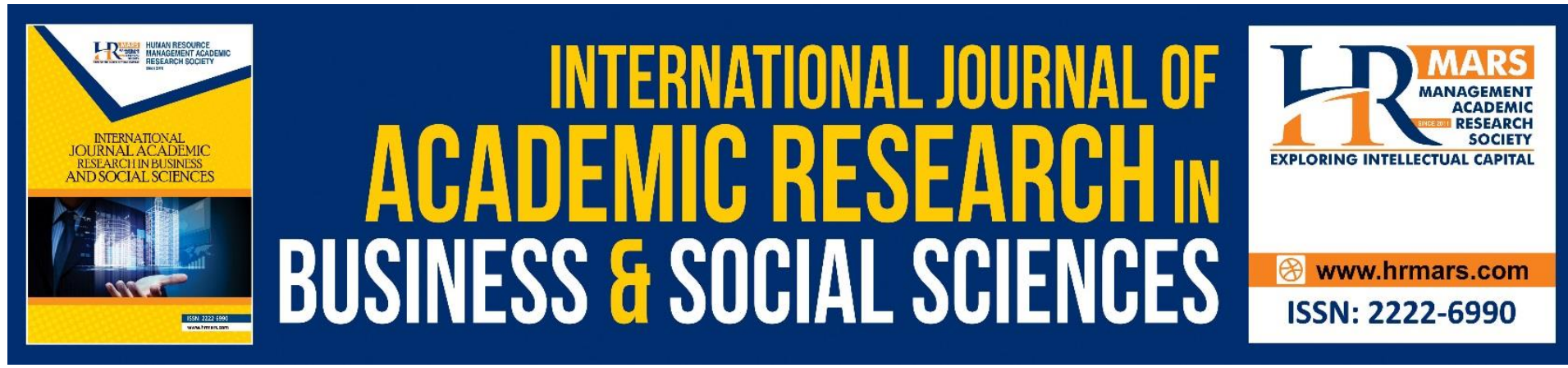

\title{
Relationship Between Service Quality and Customer Satisfaction in Outdoor Services Activities: A Case Study of Rentas Adventure Group
}

\author{
Muhammad Wafi A. Rahman, Nur Dalilah Dahlan, Nurul \\ Hasanah Abdul Razak, Rozita Abdul Latif, Siti Aida Lamat \\ Faculty of Sports Science and Recreation, Universiti Teknologi MARA (UiTM), Cawangan \\ Negeri Sembilan, Kampus Seremban \\ Email: wafiarahman@uitm.edu.my
}

\begin{abstract}
The aim of this is to identify the relationship between service quality and customer satisfaction in the outdoor activities service by Rentas Adventure Group. The SERVQUAL model was adopted to measure the service quality provided, which contributes to customer satisfaction. Questionnaires were distributed among 250 customers of Rentas Adventure Group. An easy random sampling technique was used to determine the sample size, and 218 respondents had given their prompt feedback towards the questionnaire distributed. Research questions and objectives were set. Descriptive statistics comprising the percentage, the mean, and standard deviation were used for data presentation and analysis. Correlation analysis was employed to evaluate the relationship between service quality and customer satisfaction. The study reveals that service quality affects customer satisfaction and a relationship between service quality and customer satisfaction. The researcher concluded that the organization needs to regularly enhance and monitor its service quality because of its effects on customer satisfaction. To ensure that customer satisfaction is high, organizations must first know the customers' expectations and how they can meet such expectations. In providing the customer's satisfaction could be improved, the organizations recommended seeking feedback from the customers to improve it in the future.
\end{abstract}

Keywords: Service Quality, Customer Satisfaction, Customer, Service

\section{Introduction}

There are many studies of service quality in various fields of services. Service quality studies are valid and legitimate to be done in any area of services and products. The study's main reason is to determine whether the customers are satisfied with the organization's services or products. Several critical determinants of service quality dimensions could measure the customers' satisfaction regarding understanding the customers' expectations and satisfaction. To satisfied clients for the recreational company, services are needed. Such 
facilities are functional and vary from provider to service provider. An individual may also define the service as an "immaterial bid" in return for money, as any undefined gesture or success of a party that results in possession of no other party (Kotler \& Keller, 2009). Performance frequently depends on the nature of an offer that can please or infuriate the consumer. Outdoor activities and outdoor sports are quality expectations to which consumer beliefs fulfill their standards and surpass them. The way customers are served in a good or weak company may also be a quality service.

A study done by Pakurár et al., 2019 focused on customer satisfaction by implementing the Service Quality (SERVQUAL) with five dimensions in evaluating service quality and customers' satisfaction: reliability, responsiveness, assurance, empathy, tangibility employee competencies, access, and financial aspect. Karaket \& Lin (2019) stated that they focused on the tourists' expectations and perceived satisfaction with the quality of one of the recreational farms in Taiwan. They have reported a positive result that means the recreational farm's services are good and the tourists' expectations were met. They have concluded that based on five service quality dimensions studied (assurance, empathy, tangibles, reliability, and responsiveness), they all show a positive result, describing the customers are satisfied with the services.

In Malaysia, a study was done by Ching \& Goh, 2015 regarding the intangible values with the tourists' motivations at Pahang National Park reported that intangible aspects such as recreational activity, existential values, culture, etc., are very subjective to be measured. In order to provide consistent and high-quality services for the customer, it is important to research to study the customer's changes of behavior that are directly related to their perception of the service given by Rentas Adventure Group. According to the Founder of Rentas Adventure Group, Mr. Syafiq, the company is striving to know the customers' feedback and their impressions towards the services offered to keep improving their services as they have to compete with other outdoor service providers that offer equal services. In order to stay competitive in the market, attract more customers, and have loyal customers are essential in strengthening their position in the market and boosting the profit of their business.

Based on the issue stated in the Rentas Adventure Group and the reference to the previous studies, it can be summed up that the service quality study should be carried out further to understand the customers' expectations and their satisfaction factors. As the growing interest in service quality in the Malaysian industry is pervasive, the need to understand more about the relationship between service quality and the customer's perceptions that can lead to their satisfaction and loyalty will also be increased. Therefore, this research study is intended to measure the level of service quality at Rentas Adventure Group and the level of customer satisfaction and improve the opportunity for them to use the services again in the future. Furthermore, based on the SERVQUAL model proposed by Parasuraman, Zeithaml, and Berry (1988), this research attempts to indicate the most relevant dimensions that affect the respective industry.

\section{Methodology \\ Participants}

The research study fixated on population samples engaged in the outdoor activities given by Rentas Adventure Group. A selection of individuals will be chosen from a large number for the sample size. It will be asked questions to obtain information about the quality of the service in the Rentas Adventure Group and to identify their level of satisfaction. The study 
sample consisted of 218 total respondents who engaged in the outdoor recreation activities at Rentas Adventure Group. The sample consisted of male $(n=113)$ and female $(n=105)$, in terms of race, Malay $(n=87)$, Indian $(n=66)$ and Chinese $(n=65)$ and in terms of range of age $18-30(n=106), 31-40(n=58)$ and 41-50 $(n=54)$.

\section{Instrumentation}

The tool that will be used in this analysis will be a series of questionnaires. The SERVQUAL scale, otherwise called the crevice to demonstrate by (Parasuraman et al., 1988), has appeared to be one of the most perfect methods to measure the quality of services given to clients. The questionnaire was split into three sections for this analysis. A collection of questions designed to obtain the respondent's socio-demographic details will be the first part. Questions including age, race, and many more will be included in this part. The second section will be a series of questions to define respondents' views on the Quality of Rentas Adventure's operation. At the same time, the third and final part of this questionnaire will be a set of questions to evaluate the customer's satisfaction with Rentas Adventure Group. In a series of questionnaires, a total of 20 questions will be asked. A five-point interval of Likert's rating scales will be administered to determine the satisfaction level of the respondents, and a five-point Likert scale will be used to evaluate overall satisfaction with the service. Cronbach's alpha values will be used for calculating the degree of accuracy of variables. A higher correlation of the respective coefficient of variables represents greater reliability. This research tests component characteristics of content validity to illustrate how accurate a questionnaire is.

\section{Data Collection Procedures}

This research was approved by the Research Ethical Committee from the Faculty of Sports Science and recreation UiTM Seremban. The information about respondents was obtained from Rentas Adventure Group Customer Service. Participants were informed about the purpose and nature of this study. The questionnaire distributes using Google form, email, WhatsApp, and the participants were given approximately 10-15 minutes to answer the questionnaire. The questionnaires were collected from all participants after they had completed them.

\section{Data Analysis}

All the data analyses were conducted using the Statistical Package for the Social Science (SPSS) Version 25.0. Descriptive analysis was utilized, and the significance level was set at 0.5 $(p<.05)$. In contrast, Spearman correlation statistical analysis was used to identify the relationship between customer satisfaction and service quality towards Rentas Adventure Group. Coefficient $r$ should be between +1 or -1 , with the absolute values of the Pearson correlation coefficients falling between 0 and 1 (Samuels \& Gilchrist, 2014).

\section{Results}

Table 1 shows the mean and standard deviation for five dimensions of variable service quality and variable customer satisfaction. Data from the descriptive analysis revealed that the dimension of service quality that has the highest mean is "reliability," which indicated 2.99 ( $\mathrm{SD}=.81$ ), and the second is "tangibility" with 2.93 (SD=.74). The "empathy" rank number third, which indicated a mean 2.87 (SD=.76), the next is "responsiveness," which 
indicated a mean $2.85(\mathrm{SD}=.79)$ and followed by "assurance" $2.84(\mathrm{SD}=.81)$. Finally, the variable customer satisfaction has a mean of $0.55(\mathrm{SD}=.29)$.

Table 1: Descriptive statistics of service quality dimensions and customer's satisfaction

\begin{tabular}{llll}
\hline Variables & Dimensions & M & SD \\
\hline Service quality & Tangibility & 2.93 & .74 \\
& Reliability & 2.99 & .81 \\
& Responsiveness & 2.85 & .79 \\
& Assurance & 2.84 & .81 \\
& Empathy & 2.87 & .76 \\
Customer's satisfaction & & 0.55 & .29
\end{tabular}

Spearman's Rank-Order Correlation was used to analyze this relationship study to conduct the relationship between service quality and customer satisfaction. Based on Table 2, the results of the study revealed a negative weak correlation between service quality and customer satisfaction. $r_{s}=-.18, p<.01$.

Table 2: Correlation Results

\begin{tabular}{|c|c|c|c|c|}
\hline Variable & M & SD & 1 & 2 \\
\hline 1. Service quality & 2.90 & 0.51 & 1.00 & $-0.18^{* *}$ \\
\hline
\end{tabular}

\begin{tabular}{lllll} 
& 0.55 & 0.29 & $-0.18 * *$ & 1.00 \\
\hline .01 & & &
\end{tabular}

\section{Discussion}

The service quality provided by Rentas Adventure Group is evaluated based on five dimensions which are tangibility, reliability, responsiveness, assurance, and empathy. Based on the findings obtained, it showed that reliability has the highest mean of service quality dimension and is followed by tangibility. In terms of correlation, the result illustrated a significant correlation between service quality and customers' satisfaction. These analyses support the claims made by Allan, 2016, and Yang et al., 2017, that service quality indeed does positively influence customer satisfaction. For further discussion, each aspect of service quality is explained in detail.

Firstly, the evaluation on the element of tangibility towards customer satisfaction. It can be seen that there is a correlation between service quality and customers' satisfaction. In agreement with the finding reported by Karaket \& Lin (2019) as tangibles can be measured by judging the facilities having modern equipment and decoration too. It can be the influencing factor that leads to customer satisfaction. In addition, from the researchers' point of view, it can be seen that the facilities in terms of the equipment and decoration provided at Rentas Adventure group fulfill the customers' needs. At the same time, they become the judging indicator of customer satisfaction. 
Secondly, the influence of reliability on customer satisfaction is measured. Based on the correlation analysis, it was found that there is a correlation between service quality which is measured in terms of reliability towards customer satisfaction. The reliability can be observed towards the ability of the service provider to deliver the services accurately as promises. As claimed by Odlanicka- Poczobutt \& Szmal (2020), few quality criteria describe reliability. It can be seen through the reliable and comprehensive services performed correctly to the customers as well as the excellent documentation presented. It could also be determined by observing whether the places have a safe surrounding, clean and convenient for the customers (Karaket $\&$ Lin, 2019). As a result, it contributes to customer satisfaction to be a part of the organization in utilizing the services provided. In detail, it can be proved through the service provided by Rentas Adventure Group as they prioritize their customers' safety and comfort as they carried out the research first regarding the places for the activities conducted. This situation proved that the respective organization concerns about their customers. During the briefing, the activity participants will be provided with a copy of safety concern to ensure everybody has a clear overview. The excellent service provided by Rentas Adventure Group in terms of reliability has a significant impact on customer satisfaction.

In addition, the next aspect of service quality is responsiveness. The result from the data collected found that there was no significant difference between responsiveness in service quality towards customer satisfaction. In this particular situation, the role of staff in Rentas Adventure Group plays an important role in helping and assisting the customers in getting precise information regarding the service provided. As stated by Odlanicka-Poczobutt, \& Szmal (2020), responsiveness can be of various types, which could be the quick response of employees towards the customer's need. Furthermore, the professionals and experts help solve the customer's problem and the clear information on crucial things such as the date of services provided to customers. The quick response provided positively contributes to outstanding customer satisfaction towards the service provided. It can be seen how responsive the employee in Rentas Adventure Group answered all the queries from their customers to clarify their service. In line with that, the customers could get clear information regarding the service provided. As a result, it could be one indicator that influences customer satisfaction towards the service provided.

In terms of assurance, it is about how to gain customers' confidence towards the service provided. Based on the findings obtained, it showed that there is a significant correlation between assurance as a part of service quality towards customer satisfaction. For this particular study, assurance is an important aspect, especially for high-risk services such as outdoor activities where the customer will always feel uncertain about their safety and the outcomes of the activities. It is also related to the confidence towards the employee's knowledge and skills in the services. In ensuring the customers showed their satisfaction towards the service quality, the employees of Rentas Adventure Group must portray convincing and friendly manners to the customers to make sure the customers feel assured with their services. Based on the observation, it can be seen that employees of Rentas Adventure Group have broad knowledge and skill on how to manage high-risk activities. In line with that, the customer feels secure and safe throughout the activities. The situation leads to a high level of customer satisfaction towards the service quality provided by Rentas 
Group Adventure. It is supported by Karaket \& Lin (2019) on how assurance influences customer satisfaction.

From the aspect of empathy, it is correlated with customer satisfaction. As claimed by Temba, 2013, empathy can also be described as the organization providing caring, individualized attention to their needy customers. In this present situation, the employees of Rentas Adventure Group play a significant role in gaining outstanding customer satisfaction by serving their customers with kindness and courtesy and providing employees approach for a better understanding of the customers' needs (Odlanicka-Poczobutt \& Szmal, 2020). As a result, great customer satisfaction can be achieved with the concern shown by the employees. In detail, it can be seen clearly through the behavior and attitude shown by the employees of Rentas Adventure Group. For example, during the program, the employees of the respective company shown their care and concern towards the participants.

An example is when the participants had difficulty preparing themselves with the equipment before the activity hiking water rafting. The employees give a hand in helping the participants to ensure they are well-prepared with the safety equipment features. Based on the situation, it can be claimed that the employees portrayed their empathy in fulfilling the customers' needs. Hence, it gives significant influence towards customer satisfaction for the service provided. Overall, it proved that the level of service greatly influences the respondent's satisfaction that they were presented with. The aspect in service quality is in accordance with the dimension in the SERVQUAL model, which is to evaluate its effect on customer satisfaction.

\section{Conclusion and Recommendation}

Based on the findings, this study showed a negative weak correlation between service quality and customer satisfaction. Maybe there are other factors behind the measurement that deprived them of being related. The reason could be that some of the respondents might forget the quality of service offered by the service provider. Since this study is conducted online during Pandemic covid 19, this is considered a limitation of the researcher to get a truthful answer related to customer satisfaction and service quality. However, good service quality leads to customer satisfaction and makes the company more competitive in the market. High service quality can be achieved by identifying problems in the service and determining measures for service performance and outcomes and the level of customer satisfaction.

Meanwhile, descriptive statistics of service quality dimensions and customer satisfaction showed that the most influencing aspect of service quality towards customer satisfaction is reliability. It is linked with the convenient environment, which enhances customer satisfaction towards service quality of the respective organization. For outstanding customer satisfaction, all aspects of service quality need an improvement and enhancement to ensure they prioritize customers in their service. Overall, it can be seen clearly that service quality has a relatively significant impact on customer satisfaction. The effect seems to be significant if the service quality reaches high levels. The information collected from this research will be beneficial as it could help the researchers find an effective way to improve service quality which leads to customer satisfaction. This study focused on service quality in terms of tangibility, reliability, responsiveness, assurance, and empathy. The management of Rentas Adventure Group needs regular monitoring in evaluating their service quality through the 
provided services such as organizer for outdoor events and an outdoor event consultant. Customer satisfaction is crucial to ensure the service provided gains customer interest to be a part of them. It is suggested that future research increase the number of samples because the larger the sample size, the more reliable the data collected from the questionnaires. For future research, also are suggested to make a comparison between the demographic profile among the respondents towards customer satisfaction in the outdoor activities services.

In conclusion, it was found that there is a significant correlation between service quality and customer satisfaction. Hence, it showed evidence for the direct effect of service quality on customer satisfaction. However, consistent effort is needed to sustain and improve the service quality level rendered to the customers to ensure the services provided gain customers' interest and preference. In addition, customer expectations would be changing over time, in line with that Rentas Adventure Group need to improvise the service according to customers' needs and demand.

\section{References}

Allan, M. (2016). The Relationship Between Service Quality and Customer Satisfaction and Retention in Ghana's Luxury Hotels. IUP Journal of Marketing Management, 15(4), 6083.

Ching, F. E., \& Goh, H. C. (2015). Intangible values and tourists' motivations: The case of the Pahang National Park. GEOGRAFIA OnlineTM Malaysian Journal of Society and Space, 11(3), 10-20. http://www.ukm.my/geografia/images/upload/2xx.abstract-geografiamac15-Fei\&Hong-edam.pdf

Karaket, C. N., \& Lin, N. (2019). The Evaluation of Recreational Farm Service Quality: The Application of SERVQUAL Model. Retrieved from https://card.org.tw/uploads/media/36353565baa37a5285153fdbcca71e4e.pdf

Kotler, P., \& Caslione, J. (2009). More Praise for Chaotics from Around the World. In International Business.

Odlanicka-Poczobutt, M., \& Szmal, A. (2020). Evaluation of The Customer Service Quality with Servqual Method in The Chosen Company- Part li Personnel Perspective. Zeszyty Naukowe. Organizacja i Zarzqdzanie/Politechnika Ślqska, 148, 565-576.

Pakurár, M., Haddad, H., Nagy, J., Popp, J., \& Oláh, J. (2019). The service quality dimensions that affect customer satisfaction in the Jordanian banking sector. Sustainability, 11(4), 1113.

Parasuraman, A., Valarie, A. Z., \& Leonard, L. B. (1988). SERVQUAL: A Multiple-Item Scale for Measuring Consumer Perceptions of Service Quality. Journal of Retailing and Marketing Studies, 64(1), 12-40.

Temba, M. (2013). The assessment of service quality and customer satisfaction using SERVQUAL Model: The Case Study of Tanzania Telecommunications Company Limited (TTCL). Doctoral dissertation, The Open University of Tanzania.

Yang, K. F., Yang, H. W., Chang, W. Y., \& Chien, H. K. (2017). The effect of service quality among customer satisfaction, brand loyalty and brand image. 2017 IEEE International Conference on Industrial Engineering and Engineering Management (IEEM), 22862290. https://doi.org/10.1109/IEEM.2017.8290299 